\title{
EASTERN NILE AT CROSSROADS: PRESERVATION AND UTILIZATION CONCERNS IN FOCUS
}

\author{
Elias N. Stebek*
}

\section{Introductory Remarks}

"Yabayin lij wuha temaw" is an Amharic proverb that has the theme: "thirst at the bank of a stream" or "shortages in the midst of plenty." The proverb literally means "Nile's child got thirsty." A question I had once raised in one of my elementary classes was whether a person can be considered child of a river. I recall that my Amharic Grammar teacher didn't answer the question, but instead subtly relayed it back to the class so that we could explore the core message of the proverb.

Indeed, we human beings are children of the air we breathe (without which we can't survive beyond few minutes), the water we drink (that constitute 60 to $80 \%$ of the human body and without which we can't stay alive beyond a few days). We are also children of the soil and energy (heat, light...) that nurture our crops and that enable us live our lives as generations come and go. The words "soil to soil and ashes to ashes" signify this truth.

Ancient Egyptians believed that Ptah was the Nile god and that his "head supported the sky, his feet rested upon the earth". They also believed that the sun and the moon were the eyes of Ptah and that air came from his nostrils and "the Nile from his mouth. ... Egypt's first temple was created to Ptah by King Memes."

Such reverence to the source of the Nile was long forsaken by Egypt who has been (for over a century) pursuing a geopolitical strategy towards controlling the utilization of the Nile waters, rather than equitably sharing it with upstream riparians. As decades rolled on, however, development of international law towards the principle of equitable and reasonable utilization and the current concern for the protection of the Nile basin ecosystem seem to necessitate changes that require fraternal concessions towards mutual benefit and ultimate regional integration.

* Dean, Faculty of Law, St. Mary’s University College
${ }^{1}$ Machenzie, in Yacob Arsano, Ethiopia and the Nile: Dilemmas of National and Regional Hydropolitics, $\mathrm{PhD}$ dissertation (University of Zurich, 2004) p.42) 
For the purpose of delimiting its scope, this paper does not cover the Equatorial Nile Basin, and focuses on Eastern Nile which mainly involves Egypt, Ethiopia and Sudan. The Eastern Nile basin includes three rivers that have their headwaters in Ethiopia, namely the Abbay (Blue Nile), the Tekezie-Atbara and the Baro-Akobo-Sobat which respectively contribute $59 \%, 13 \%$ and $14 \%$ of the entire water volume that flows towards Sudan and Egypt. This paper briefly addresses issues which are indeed sine qua non conditions for the protection and equitable utilization of the Nile to the benefit of present and future generations in all riparian states.

Section 1 highlights the current adverse environmental symptoms in the Eastern Nile basin and the path that led to its current critical state. The second section briefly discusses the population and water resource mismatch, inefficient utilization and the danger of declining water discharge of Eastern Nile. In sections 3 and 4, the principles of 'equitable utilization' and 'the noharm rule' have been briefly discussed in the context of the Eastern Nile watercourse. And finally, Section 5 and the concluding remarks forward the issues of cooperation and sustainable utilization towards 'win-win' mutual survival.

\section{Ecosystem Degradation and Hydropolitics}

\section{1- Hydropolitical tensions and nature's wake-up calls}

Generations of Egyptians harboured the suspicion of possible interference by Ethiopia in the flow of the Nile. Significant decrease in the volume of Nile waters was (in the minds of generations of Egyptians) attributed to possible Ethiopian intervention rather than seasonal rainfall variations. Collins states "a disastrous dearth of water from 944 to 953 and from 1059 to 1066" and the extremely low Nile flows that were reported to have produced a catastrophic famine in Egypt from 1180 to 1182, during which tens of thousands died. "In 1201, a third of the population of Cairo is reported to have perished. In desperation, the sultans of Egypt were supposedly to have sent ambassadors bearing tribute for the Ethiopians so that they would not obstruct the waters."2

Eventually, this legend of Ethiopian obstruction "became belief. James Bruce of Kinnaird, the Scottish traveler who lived in Ethiopia from 1769 to 1771 recounts a letter from the King of Ethiopia to the Pasha of Egypt in 1704, threatening to cut off the (Nile) water."3 Ethiopian emperors were merely

\footnotetext{
${ }^{2}$ Robert O. Collins, The Waters of the Nile: (Oxford Clarendon Press, 1990) Page 3 Hydropolitics and the Jonglei Canal ${ }^{3}$ Id. at 4
} 
expressing symbolic threat in reaction to mistreatment of Coptic Christians in Egypt. However, Egyptian rulers didn't realize that Ethiopia had neither the capability nor the need to obstruct the Nile.

Egypt and its civilization are indeed children of the Nile which contributes for $97 \%$ of its water consumption. Such dependence and the Nile-diversion syndrome thus explain the attempts of various Egyptian rulers to control the source of the Nile headwaters especially after Egypt enhanced its efforts in harnessing the Nile for irrigation since the $19^{\text {th }}$ Century.

Attempts to control the source of the Nile continued after Egypt fell under British Protectorate in 1882 through means that were more subtle, such as the 1902 Anglo-Ethiopian Treaty (which is beyond the scope of this paper). After Egypt's independence, its geopolitical strategy was tuned towards controlling the Nile by optimizing its utilization through the Aswan High Dam (and bilateral treaties such as its 1959 Treaty with Sudan, excluding Ethiopia from the negotiations) and meanwhile obstructing Ethiopia's meaningful utilization of the headwaters by blocking international financing for various projects.

Egypt's desire to leave no stone unturned that would shake Ethiopia's political stability and territorial integrity had always been apparent despite seemingly tranquil diplomatic relations and formal statements. "In 1979, Egyptian President Anwar Sadat said: The only matter that could take Egypt to war again is water." 4 A similar statement was made by the former Egyptian Prime Minister (Butros- Butros- Ghali) who "predicted that the next war in the Middle East would be fought over the waters of the Nile, not politics."5

These threats of war in the event of Ethiopia's significant utilization of the upstream Nile were the most explicit expressions regarding Egypt's long-held desire to have overwhelming dominance over the utilization of the Nile waters. President Sadat and Mr. Ghali (same as Ethiopia's Emperors) were most likely making statements that were figurative rather than real because wars over waters inevitably lead to a 'lose-lose' destruction. However, the motive expressed in these statements can't be ruled out with regard to proxy wars conducted with persistent simulation of noninvolvement. In retrospect, Ethiopia's political instability and economic

\footnotetext{
4 "Patricia Kameri-Mbote, Water, Conflict Center for Scholars, (January 2007, No.4) and Cooperation: Lessons from the Nile Pg. 1 www.wilsoncenter.org/water River Basin, Woodrow Wilson International ${ }^{5}$ Ibid
} 
problems that seemed 'beneficial' for Egypt's short-term dominance over the Nile waters, has in fact enhanced poverty and environmental degradation of the Upper Nile basin thereby adversely affecting the long term needs of Egypt and Sudan.

The current environmental degradation in upstream Eastern Nile basin is mainly attributable to the cumulative result of decades of deforestation and watershed mismanagement caused by the prolonged economic, social and political problems that Ethiopia has been forced to go through, and any external pressure towards this turmoil has directly contributed to the current state of the basin. Unless this trend is reversed, the forthcoming decades might possibly witness the further degradation and desertification of the basin that could cause the eventual (albeit gradual) drying up of the watercourse and along with it: the probable end of Egyptian agriculture through surface fresh waters.

Even worse, global warming and erratic monsoon rain variations might hasten this looming doom. The drying up of Lake Horomaya (Alemaya) in Harar, the dwindling volume of most of Ethiopian lakes, the increasingly worsening siltation and sedimentation throughout the Nile basin, the drying up of many streams and springs that we knew since childhood, and many other symptoms are indeed Mother Nature's wake up calls.

\section{2- The ecological cost of agriculture}

Species on earth have so far encountered five extinctions since the severe and sudden climate change of global cooling (circa 440 mya). According to the paleontologist, Dr. Niles Eldredge, we are in the third phase of the sixth extinction. "The first phase began (about 100,000 years ago) shortly after Homo Sapiens evolved in Africa and the anatomically modern humans began migrating out of Africa and spreading throughout the world" during which many native species became extinct. The second wave of the sixth extinction of terrestrial species "began about 10,000 years ago when humans turned to agriculture. ... It started with the invention of agriculture perhaps first in the Natuflan culture of the Middle East.”,

Dr. Eldredge further noted that "Agriculture represents the single most profound ecological change in the entire 3.5 billion-year history of life." With this invention, he added "humans did not have to interact with other species for survival, and so could manipulate other species for their own use", and

${ }^{6}$ Id. at 4 
humans “did not have to adhere to the ecosystem's carrying capacity, and so could overpopulate". ${ }^{7}$ Eldredge remarked that "conservation measures, sustainable development, and, ultimately, stabilization of human population numbers and consumption patterns" could possibly mitigate the adverse effects of the Sixth Extinction so that is would not be as grave as the third global extinction (some 245 mya) during which " $90 \%$ of the world's species were lost." 8

Humans, according to Eldredge are the first species to stop living inside local ecosystems. "All other species, including our ancestral hominid ancestors, all pre-agricultural humans, and remnant hunter-gatherer societies still extant exist as semi-isolated populations playing specific roles (i.e. have niches) in local ecosystems." With the advent of agriculture, "humans converted land to produce one or two food crops, with all other native plant species now classified as unwanted 'weeds' ..." 9

Human beings are part of their ecological environment. "The Chinese philosophers believed that man must invariably be seen as inseparable from nature and in oneness with the universe."10 And as Pathak remarked "man ... holds a higher position in the tree of evolution, but that only invests him with greater responsibility to the non-human components of the ecological family."11

Professor Joseph W. Dellapenna states that about “12,000 years ago, massive global climate change accompanied the end of the Ice Ages, turning the vast region stretching across northern Africa and southwestern Asia from a humid region of rivers, forests, and grass into immense deserts, of which the Sahara is the best known." As a result, Dellapenna added, "hunter-gatherers fleeing the Sahara descended into the Nile Valley, where some of them discovered that by deliberately planting seeds they had gathered and stored". They could thus "multiply the yield and sustain their population despite the increasing aridity of the surrounding lands. This was the beginning of agriculture and of civilization as we know it." 12

\footnotetext{
${ }^{7}$ Id. at 3

${ }^{8} \mathrm{Id}$, at 4

${ }^{9}$ Id. at 3

${ }^{10}$ R. S. Pathak , “The Human Rights System as Conceptual Framework for Environmental Law", (Environmental Change and International Law: New challenges and dimensions, Edited by Edith Brown Weiss, United Nations University Press, 1992) p.

${ }^{11}$ Id. at $223-224$

12 Joseph W. Dellapenna, “The Nile as a Legal and Political Structure" (Conflict and Cooperation Related to International Water Resources: Historical Perspectives, IHP-VI Technical Documents on Hydrology (TDH) N0. 62 UNESCO, Paris, 2002, Page 35 
Although necessity led to invention, humans ultimately became imprudent masters of the ecosystem thereby causing ecological disequilibrium that could ultimately render human life difficult, if not impossible. With the advent of the Industrial Revolution this threat against the ecosystem has further increased at a meteoric rate.

\section{3- Green -turned red- mountains}

For centuries, the greenery of Ethiopian highlands was witnessed by many writers who had been direct observers. In drastic contrast to the ecosystem that prevailed for millennia, the following is a recent statement by Abbas ElTarabily about what he observed regarding the eroded mountains whose currently unprotected soil is being stripped by floods and gushed into the Abbay (Blue Nile) River and its tributaries:

"I am back from Ethiopia, the source of the (over $80 \%$ ) of Nile water which created Egypt. In fact, Egypt was born in Ethiopia and from the red mountains of Ethiopia came the water, which is the stuff of our life and the silt that created the fertility of Egyptian soil. ... I was telling myself that it is from this place that the journey of the great river starts and carves the red rocks of Ethiopia leaving thousands of canyons and rifts that seemed to be the blood veins of the Egyptian body."13

Such soil shipment seems to have now reached at its level of diminishing returns. The sustainability of the Blue Nile in the decades and centuries to come should thus be the mutual concern of all states of the Eastern Nile basin. The following indicates the current challenges regarding environmental degradation in the Eastern Nile basin:

Populations are growing fast, placing additional demands on scarce water and other natural resources. Erosion, a natural process in the highland areas, has been exacerbated by deforestation, overgrazing, and cultivation of marginal lands by poor farmers. Land degradation is very serious in parts of the basin, contributing to low soil productivity and poor agricultural production. High erosion also causes downstream sedimentation, which decreases reservoir life, reduces the efficiency of hydropower production and irrigation, erodes stream-banks, and damages habitats. Rainfall and river flows are highly variable and unpredictable, resulting in endemic droughts and floods. Damage caused by variable rainfall and unregulated river flows is a major constraint to the economies of the Eastern Nile. ${ }^{14}$

\footnotetext{
${ }^{13}$ Abbas El- Tarabily, Editor-in-Chief of the Al-Wafd Newspaper, 10 Feb. 2002 in Yacob Arsano, Supra Note 1, at 44

${ }^{14}$ Nile Basin Initiative: Eastern Nile Subsidiary Action Plan, Joint Multipurpose Program, JMP Launch Overview, page 1. www.nilebasin.org
} 
The Planning Phase Project Document of Watershed Rehabilitation of the Nile (WREN, November 2003), states the environmental degradation and its adverse impact on the Blue Nile watercourse:

The average annual discharge of the Blue Nile River is estimated to be 50.1 $\mathrm{Km}^{3}$, and over $80 \%$ of the flow to the lower Nile originates in the Ethiopian plateaux.

The deforestation of Ethiopian highlands, which form the upper catchment area of the Blue Nile coupled with extensive cultivation and overgrazing has resulted in the loss of vegetation cover, which in turn has resulted in massive erosion of soil. The annual soil loss from these steep-sloped highlands is estimated to vary between 50 to 170 tons per hectare and that translates to an average soil depth reduction of 8 millimeters per year. Soil erosion is by far the main cause of land degradation in the Blue Nile catchment area and has resulted in the reduction of agricultural productivity of the land and the weakening of the food security of the communities. Moreover, the massive amount of sediment transported by the Blue Nile from the Ethiopian highlands to lower Nile riparian countries of Sudan and Egypt has a detrimental effect on dams, hydroelectric stations, irrigation channels and aquatic life. In addition, the loss of vegetation cover in the Ethiopian highlands has led to increased surface run-off, low infiltration rate and replenishment of the ground water, landslides and higher frequency of floods in the lower Nile riparian countries. ${ }^{15}$

The highlands of the Blue Nile watershed are densely populated, and farmers till the sloppy mountains, chop fuel wood from the sparse trees/bushes and overgraze the barren grounds. It is thus necessary to preserve the steep highlands for reforestation and the moderately sloppy plots for vegetation through significant relocation of farmers to the lowlands of the basin so that they can be engaged in agriculture with modern irrigation. This clearly requires meaningful utilization of the upper Nile waters and construction of reservoirs in Ethiopia.

\section{Population, Inefficient Irrigation and Changes in Nile's Discharge}

Fresh water resources are not as abundant as we used to presume. Next to air, water was regarded as the most abundant and accessible resource. And, until the $19^{\text {th }}$ Century international law merely regulated the navigational uses of watercourses, and it was thereafter that the non-navigational uses of transboundary water courses began to be issues of dispute and concern.

15 Watershed Rehabilitation of the Nile (WREN), Project Document: Planning Phase (Prepared by ICRAF- Kenya, VITRI- Finland, EARO- Ethiopia, FNC- Sudan) November 2003, Page 4 
Upon first impression, we feel that nature has availed us with abundant fresh water resources. It is true that " $97 \%$ of the world's surface is covered by water", however, "94\% of this water is contained in the world's oceans, and therefore is of little use for drinking, agricultural or industrial purposes." Moreover, over two thirds of the 3\% of fresh water is not accessible because it is "locked away in the polar ice caps, glaciers or deep underground aquifers." It is thus "estimated that only $0.36 \%$ of the world's water contained in rivers, lakes and swamps is sufficiently accessible to be considered as a renewable fresh water resource."16

\section{1- Population Growth}

Sherk et al state the uneven distribution of water around the world and the alarming growth of world's population which had more than doubled from 2.5 billion in 1950 to six billion in 40 years. "It is estimated that ... by 2100 (world population will reach) around 12 billion. In stark contrast to this ballooning growth of the world's population, the earth's supply of freshwater remains relatively constant at 'an unchanging 14,000 trillion cubic meters a year.” As Sherk et al noted “...it is estimated that by the year 2025, at least 30 countries will be unable to supply these minimal requirements. ${ }^{17}$

Professor McCaffrey holds the same view and cites United Nations forecasts that world population could reach some 9 billion by 2050. "Most of this growth continues to occur in the Third World, especially Africa and Asia.",18 He further discusses the increasing concentration in urban areas and the rising demand for water. He cites Mexico City as an example. "In 1982 (the City) had to pump water from a distance of $100 \mathrm{kms}$ and from 1,000 meters below the city. By the 1990s, rapid population growth required the city to withdraw additional water from 200 kilometers away and 2,000 meters lower"19

\section{2- Inefficient irrigation}

The demand for fresh waters has further been inflated by inefficient and unsustainable use of water "which could be eliminated through improved irriga-

\footnotetext{
${ }^{16}$ George William Sherk, Patricia Wouters and Samantha Rochford, "Water Wars in the Near Future?" Reconciling Competing Claims for the World's Diminishing Freshwater Resources - The Challenge of the Next Millennium (The Center for Energy, Petroleum and Mineral Law and Policy -

${ }^{17} I d$, at 4

18 Stephen McCaffrey, The Law of International Watercourses: Non-Navigational Uses, (Oxford University Press, 2001), p. 6

${ }^{19}$ Id. at 7
} 
tion practices". One of the factors for inflated fresh water consumption is the replacement of traditional crops "with new high-yielding varieties and those that earn foreign exchange, but ... (which) consume significantly more water that their predecessors. ...”20 Moreover, the irrigation system in Egypt that is almost a century old "is still practiced and the canals and barrages built in this century are profligate wasters of water, creating a conveyance loss by evaporation in the canals and basins of probably another 10 billion cubic meters" in addition to the evaporation loss at Aswan high dam. ${ }^{21}$

\section{3- Changes in Nile’s discharge}

Upon the construction of the high dam, Egypt's insecurity from drought and famine was assumed to be a problem of the past. However, the high dam cannot deliver the Nile Waters, but can only harness and store floods and retain the waters from flowing into the Mediterranean. "(T)he Egyptian water deficit in 1988 (owing to rainfall shortage on Ethiopian highlands) amounted to 12 billion cubic meters." As Collins remarked, it was a perplexing situation for Egyptians. " The euphoria over the completion of the Sadd al-Aali did not take into consideration the acts of man, nor the seeming change of atmospheric patterns producing 'periodicity'. 22 Collins states the steady decline in the volume of the Nile.

... From 1977 there has been a precipitous decrease in the volume of the Nile Water, 86 percent of which comes from the Ethiopian plateaux. From 1870 to $1987 \ldots$ the average annual flow of the Nile (for 117 years) as measured at Aswan was 88 billion cubic meters. This generous volume is distorted by the high flows from 1870 to 1899 . A more accurate reading ... is an average mean annual flow from 1899 to 1959 of 84 billion cubic meters. During the $20^{\text {th }}$ Century the Nile flows fluctuated from 120 billion cubic meters in 1916 to 42 billion cubic meters in 1984. During ... 1977 to 1987, however, the average mean annual flow of the Nile has been recorded as 72 billion cubic meters, but what is disturbing is the plunge from 1984 to 1987, when the Nile flows declined by 28 per cent from 72 billion to 52 billion cubic meters. ${ }^{23}$

John Waterbury's book verifies the same reality. Based on analysis of the flood records from the natural yield of Main Nile at Aswan for hydrologic years from 1870/71 to 1975/76, Waterbury noted that "least square regression analysis yields a best fitting line sloping downward ... at an

\begin{tabular}{l|l}
\hline${ }^{20}$ Ibid & ${ }^{22}$ Id. at 404 \\
${ }^{21}$ Collins, Supra Note 2, at 403 & ${ }^{23}$ Id. at 402
\end{tabular} 
average annual rate decline of 228 million cubic meters."24 Waterbury further underlined that the upsurge or decline of Nile's annual discharge during the decades ahead would be crucial to development strategies and prospects of riparians. The flow since 1977 indicates extreme events and variations in the discharge of the Nile. In case future trends lean towards consistent decline of Eastern Nile's discharge (owing to factors such as environmental degradation, climate change and other factors) it would be detrimental to the interest of all riparians.

\section{Practical aspects of Equitable Utilization}

\section{1- Article 5 of the 1997 UN Watercourses Convention}

The principle of equitable utilization is among the core rules embodied in the 1997 UN Convention on the Law of the Non-navigational Uses of International Watercourses (hereinafter referred to as the $1997 \mathrm{UN}$ Watercourses Convention). The first sentence of Article 5/1 provides that "[w]atercourse states shall in their respective territories utilize an international watercourse in an equitable and reasonable manner". This clearly recognizes sovereignty over natural resources and the conditions attached thereof.

The second sentence of the provision makes particular reference to the right of watercourse states to use and develop international watercourse "with a view to attaining optimal and sustainable utilization thereof and benefits therefrom, taking into account the interests of the watercourse States concerned, consistent with adequate protection of the watercourse.” And, the Second Paragraph of Article 5 clearly stipulates the duty of watercourse States to "participate in the use, development and protection of an international watercourse in an equitable and reasonable manner", and such participation includes not only the right of utilization, but also "the duty to cooperate in the protection and development thereof”.

As Judge Kooijmans stated in the ICJ decision (1999) on the dispute between Botswana and Namibia, "The 1997 Convention has not yet entered into force. ... this does not mean, however, that a number of the principles, which are formulated in the Convention have not yet become part of the corpus of international law". ${ }^{25}$ The principles enshrined in the 1997 Watercourses

\footnotetext{
${ }^{24}$ John Waterbury, Hydropolitics of the Nile, ${ }^{25}$ Case Concerning Kasikili/Sedudu Island (Syracuse University Press, 1979), p. $251 \quad$ (Botswana v. Namibia), International Court of Justice; 13 November 1999, Separate Opinion of Judge Kooijmans, Paragraph 31
} 
Convention are thus applicable to the extent that they are expressions of customary international law or general principles accepted by the major legal systems.

Likewise, the ILC commentary on Article 5 of the 1997 Convention states that "a survey of all available evidence of the general practice of States, accepted as law ... reveals that there is overwhelming support for the doctrine of equitable utilization as a general rule of law for the determination of the rights and obligations of states in this field" 26

Professor Stephen McCaffrey regards Article 5 of the Convention (which sets forth the Principle of Equitable and Reasonable Utilization and Participation) as the cornerstone of the law of international watercourses. This principle requires states to "use an international watercourse in a manner that is equitable and reasonable vis-à-vis other states sharing the watercourse." It is to be noted that "the International Court of Justice, in its recent decision in the Gabcikovo-Nagymaros case, emphasized the importance of operating the project involved in the case in an equitable and reasonable manner." 27

The emphasis given to the principle of equitable utilization and protection (in the Gabcikovo-Nagymaros case) uplifts the principle onto the level of customary international law as expressed by the decision of the ICJ thereby enabling it to apply on States that haven't yet ratified the 1997 UN Watercourses Convention. This is because Article 38/1/d of the Statute of the International Court of Justice recognizes "judicial decisions and the teachings of the most highly qualified publicists, as subsidiary means for the determination of rules of (international) law.”

In the Gabcikovo-Nagymaros case (Republic of Hungary v. Slovak Federal Republic, 1997), ${ }^{28}$ the International Court of Justice has firmly established that "international rivers are shared resources and all riparian states have equal rights to enjoy both the commodity and non-commodity ecological benefits of the river" and this case "is an extremely important international and environmental protection precedent because the opinion ... clearly establishes that the doctrine of equitable apportionment is the grund norm of international water law.” 29

\footnotetext{
${ }^{26}$ ILC Commentary, Paragraph $10 \quad{ }^{28}$ Case Concerning the Gabcikovo-

27 Stephen McCaffrey, The UN Convention Nagymaros Project (Republic of Hungary v. on the Law of the Non-Navigational Uses of Slovak Federal Republic), International International Watercourses: Prospects and Court of Justice, Case No. 92, September Pitfalls, World Bank Technical Paper No. 25, 1997 414, p.19

${ }^{29}$ A. Dan Turlock, Law of Water Rights and Resources, July 2006, § 11:9
} 


\section{2- Equitable shares in the context of conflicting interests}

Allocation of scarce transboundary waters is susceptible to conflicting interests. Sherk et al state the key issues involved in such situations: "Is the upstream State entitled to use all of the water that originates on its territory? Are the prior developments of downstream States protected against subsequent uses of their upstream neighbor? How can the conflicts be resolved?’30

Contentions between states in the utilization of transboundary watercourses are invariably influenced by upstream versus down-stream interests. This was clearly manifested in doctrines such as the principle of absolute territorial sovereignty (that claims absolute freedom of action of an upstream state in utilizing transbounday waters in its territory), the principle of absolute territorial integrity (which contends that upstream states should do nothing that affects the integrity and natural flow of the watercourse towards the downstream state) and other variations of these theories.

However, the principle of equitable apportionment emerged through case laws that involved disputes among federal states within the same country -the USA. The principle has thus emerged from a setting that was relatively free from misinformed and polarized nationalism. And this principle has (with some adjustments) eventually become the governing principle under international law.

In the case of New Jersey versus New York (US Supreme Court, 1931), New Jersey contested New York's act of “diverting waters of the Delaware River, its tributaries or headwaters to increase the water supply of New York City". Justice Oliver Wendell Holmes discussed the rule of law that ought to be applied:

A river is more than an amenity, it is a treasure. It offers a necessity of life that must be rationed among those who have power over it. New York has the physical power to cut off all the water within its jurisdiction. But clearly the exercise of such a power to the destruction of the interest of lower States could not be tolerated. And on the other hand equally little could New Jersey be permitted to require New York to give up its power altogether in order that the river might come down to it undiminished. Both States have real and substantial interests in the River that must be reconciled as best they may. The different traditions and practices in different parts of the country may lead to varying results but the effort always is to secure an equitable apportionment without quibbling over formulas. ${ }^{31}$

\footnotetext{
${ }^{30}$ Sherk et al, Supra, Note 16, p.5

31 New Jersey v. New York (US Supreme Court) 283 US 336 (1931) at pp. 342-343
} 
In the Eastern Nile context, the reasoning of Justice Holmes recognizes Ethiopia's physical power over the waters within its jurisdiction subject to restraint from exercising its physical control to the destruction of the interest of the lower and middle riparians. Meanwhile, Egypt and Sudan should not require Ethiopia to give up its right of utilizing the upper watercourse altogether so that the river would come down to them undiminished.

Ethiopia's population is currently over 70 million and the amount of irrigable land in the Eastern Upper Nile Basin is extremely high. The need to meaningfully utilize its water resources is thus a necessity that is long overdue. This would raise the issue of equitable allocation of water among the riparian states of the Eastern Nile basin.

As Sherk et al noted, "the upstream users of the Nile have been unable to mounting any significant development schemes to draw upon the Nile, despite having severe food security problems which might be solved by water resources development." At present, however, "such water resource development is the country's main option, providing food security and socioeconomic development in the region through the use of irrigation and hydroelectric power." Sherk et al state that to date Egypt has adopted an aggressive stance in relation to upstream development, which has in turn led to potential sponsors of such development programmes being discouraged from providing assistance." However, such lack of funding for such projects "may soon no longer be the preventive factor in Ethiopia's plans to press ahead with the schemes. ... The strength of Egypt's resistance to upstream development is enormous, however ... it is hoped that some agreement might be reached. ${ }^{32}$

Egypt has been the only significant user of the Nile waters "throughout most of the last 5000 years", and "... Ethiopia has expressed a desire to use water for itself and negotiations have taken place already between itself and Egypt and Sudan. Just how the Nile waters are to be allocated on an 'equitable and reasonable' manner in future is not clear." Beaumont noted that "Ethiopia and the East African countries have a strong claim to use the waters of the Nile as large volumes of them are generated within their boundaries." The key question, he added, "is just how much of the water they should be allowed to use." 33

\footnotetext{
${ }^{32}$ Sherk et al, Supra, Note 16, p.9

33 Peter Beaumont, The 1997 Convention on the Law of Non-navigational Uses of International Watercourse: Its Strengths and
}

Weaknesses from a Water Management Perspective and the Need for New Workable Guidelines (Water Resources Development, Vol. 16, No. 4, 2000) p. 491 


\section{3- Definition of "reasonableness" under the 1997 Convention}

The definition of "reasonableness" of watercourse utilization has been subject of discussion ever since the principle of "equitable and reasonable utilization" came to the forefront regarding the utilization and protection of international watercourses. Although rigid definition is not feasible, there is growing consensus on the factors that determine the degree of reasonableness in the utilization of international watercourses.

In 1966, the International Law Association (56 ${ }^{\text {th }}$ Session) adopted, the Helsinki Rules on the Uses of the Waters of International Rivers. ${ }^{34}$ The principle of equitable and reasonable share in the utilization of international watercourses was enshrined in the 1966 Helsinki Rules (Article IV) and in the 1961 Salzburg Resolution of the Institute of International Law (Institut de Droit International) on the utilization of non-maritime international waters. Article 2 of the Salzburg Resolution recognized the right of a State to utilize waters that traverse or border its territory subject to "the right of utilization of other States interested in the same watercourse or hydrographic basin.” In cases of disagreement over the scope of utilization, Article 3 of the Salzburg Resolution provided that "settlement will take place on the basis of equity, taking particular account of their respective needs, as well as of other pertinent circumstances".

Article V of the Helsinki Rules define reasonableness by a list of eleven nonweighted, non-exclusive, non-exhaustive and non-preferential ${ }^{35}$ factors. The list has embodied US Case Laws of equitable apportionment, with enhanced aspects of social equity and means of managing conflicting interest. Article 6 of the 1997 Watercourses Convention has now streamlined the eleven nonexhaustive factors stated in Article V Sub-Article II of the Helsinki rules into seven factors that are to be considered as indicative grounds in evaluating the equitable utilization and protection of transboundary waters. “... The merest perusal of the standards for equitable utilization demonstrates that while equal access is guaranteed, equal shares are not. The standards are found in Article 6 of the UN Convention, which contains a long list of relevant factors" 36

Article 6 of the Convention embodies the following non-exhaustive list of factors and circumstances:

\footnotetext{
34 ILA, Report of the $52^{\text {nd }}$ Conference, ${ }^{36}$ Turlock, Supra, Note 29, § 11:8

Helsinki 1966, London 1967, pp. 484 ff

35 United Nations General Assembly,

A/CN.4/L.463/Add.4, July 8, 1991, Art. VI
} 
a) Geographic, hydrographic, hydrologic, climatic, ecological, and other factors of a natural character;

b) Social and economic needs of the watercourse nations concerned;

c) The population dependent on the watercourse in each watercourse State;

d) The effects of the use or uses of the watercourse in one watercourse nation on other watercourse nations;

e) Existing and potential uses of the watercourse;

f) Conservation, protection, development and economy of use of the water resources of the watercourse and the costs of measures taken to that effect; and

g) The availability of alternatives, or corresponding value, to a particular planned or existing use.

According to Paragraph 3 of Article 6, "the weight to be given to each factor is to be determined by its importance in comparison with that of other relevant factors. In determining what is reasonable and equitable use, all relevant factors are to be considered together and a conclusion reached on the basis of the whole. Factors "a" and " $\mathrm{f}$ " clearly articulate environmental concerns that need to be taken into account in determining the reasonable and equitable use of international water courses.

\section{4 - The issue of prior use or "historic" rights}

The factor of existing use (i.e., prior use) is one of the factors (but not the sole nor predominant factor) stated in Article 6/e in the assessment of equitable and reasonable utilization. It must also be noted that Article 6(e) does not only refer to 'existing use (prior use)' but also to 'potential use'. Prior or historic rights can of course substantiate other legal arguments based on treaties, customary international law and general principles accepted by the major legal systems. But, closer reference to various ICJ decisions, for instance, clearly indicates that claims of priority rights and historical consolidation cannot, on their own, be viable grounds for claiming rights under international law.

Historic rights have not been accepted as governing international law principles in various decisions of the International Court of Justice,. For example, in ICJ decisions regarding boundary disputes between Nigeria and Cameroon (2002), and Libya and Chad (1994), ${ }^{37}$ historic rights based on historical con-

${ }^{37}$ Case Concerning the Land and Maritime Boundary between Cameroon and Nigeria, International Court of Justice (10 ${ }^{\text {th }}$ October 2002), G. L. No. 194; and Case Concerning the Territorial Dispute (Libya Arab Jamahiriya v. Chad), International Court of Justice (3 February 1994) G. L. No.83 
solidation and the claim of 'coalescence of rights and titles' over contested regions have not been accepted by the Court as decisive grounds in the determination of the cases.

In the Lake Lanoux Arbitration ${ }^{38}$ between France and Spain the Arbitral Tribunal gave focus to the balance of rights of upstream state (France) and downstream state (Spain) rather than historic rights, The Tribunal held that "France is entitled to exercise her rights; she cannot ignore Spanish interests." Likewise, the Tribunal observed that "Spain is entitled to demand that her rights be respected and that her interests be taken into consideration." The arbitral award in fact confers the right of initiative to the upstream state provided that it takes the interest of the downstream state into consideration in a reasonable manner:

As a matter of form, the upstream State has, procedurally, a right of initiative; it is not obliged to associate the downstream State in the elaboration of its schemes. If, in the course of discussions, the downstream State submits schemes to it, the upstream State must examine them, but it has the right to give preference to the solution contained in its own scheme provided that it takes into consideration in a reasonable manner the interests of the State.

International law does not thus consider historic rights as legal grounds of acquisitive prescription, but merely as factors that can be taken into account to substantiate claims supported by treaties, customary international law or general principles recognized in the major legal systems. In effect, the volume of prior use would merely be one among the numerous factors in the reallocation of the Nile waters based on customary international law as expressed by the factors stated under Article 6 of the 1997 UN Watercourses Convention.

\section{The 'no-harm rule' in context}

\section{1- Economic and environmental dimensions of the no-harm rule}

According to Article 7 of the 1997 UN Watercourses Convention, "Watercourse States shall, in utilizing an international watercourse in their territories, take all appropriate measures to prevent the causing of significant harm to other watercourse States.” The Second Paragraph further stipulates the effects of causing significant harm to another watercourse state. Professors Damrosch et al support the following comment by Benvenisti: "By re-

${ }^{38}$ Lake Lanoux Arbitration (France v. Spain), 12 R.I.A.A. 281; 24 I.L.R. 101, Arbitral Tribunal, November 16, 1957, pp. 23, 24 
fraining from assigning property rights to existing allocations, (the no harm rule embodied in Article 7) emphasizes the necessity of negotiation, and thus increases the likelihood of equitable, optimal, and environmentally sound outcomes.” 39

The no harm principle has environmental and economic dimensions. Professor Caflisch unconditionally supports the no-harm rule from the environmental perspective as fully valid, ${ }^{40}$ but underlines the precaution that is needed in the interpretation of the no-harm rule with regard to the economic aspect of the rule: i.e. utilization of watercourses. Caflisch stated that the no-harm rule is at present of little use in the allocation of the utilizations of watercourses. "Most international waterways are at present fully exploited or even over-used. Accordingly, the issue is no longer one of not causing harm-but one of apportioning resources among competing uses and users." Thus, Caflisch added "the negative no-harm rule had to be superseded by a positive rule which would make it possible to effect such an apportionment." 41

Professor Lucius Caflisch noted that "the economic and social growth of any newcomer, in particular upstream countries, would be stunned" if the no-harm rule is applied out of context. If the no-harm rule were the only rule to apply, it "would fully protect the status quo, i.e., the existing rights of the lower riparians --Egypt and, to a lesser degree, the Sudan-- and deny the upper riparians --first and foremost Ethiopia-- any possibility of developing or expanding activities." 42

\section{2- Synthesis of the no-harm rule with equitable utilization}

The synthesis of the no-harm rule and the principle of equitable utilization has been subject of discourse among scholars and watercourse States. McCaffrey discusses the principles from contending perspectives and ultimately identifies the governing principle. "If equitable utilization is the controlling legal principle, upstream State $\underline{A}$ may develop its water resources in an equitable and reasonable manner vis-à-vis downstream States $\underline{B}$ and $\underline{C}$, even though that development would cause significant harm to their established uses." 43 And McCaffrey added: "If on the other hand, the obligation

\footnotetext{
${ }^{39}$ L. F. Damrosch, L. Henkin et al, International Law Cases and Materials, $4^{\text {th }} \mathrm{Ed}$., American Casebook Series (St. Paul, Minnesota: 2001), p. 1549

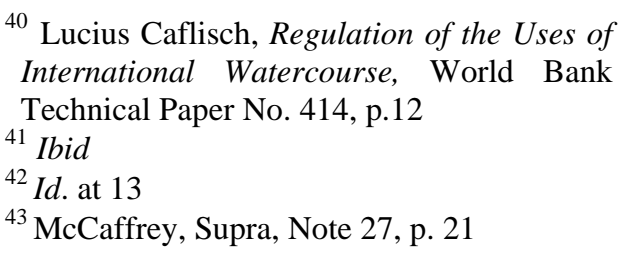


not to cause significant harm is dominant, State $\underline{A}$ could engage in no development, no matter how equitable and reasonable, that could cause States $\underline{B}$ and $\underline{C}$ significant harm.” 44

McCaffrey then discusses the various options that were debated upon before the final embodiment of these principles as a package. And whenever principles are adopted as a wholesome package, there is apparently the governing principle that forms the foundation of the synthesis whenever such principles are in conflict.

... (P)aragraph 2 of Article 7 of the Convention gives precedence to equitable utilization over the no-harm doctrine. The very existence of the second paragraph implicitly acknowledging that harm may be caused without engaging the harming state's responsibility supports this conclusion. Also indicating a recognition that significant harm may have to be tolerated by a watercourse state are the numerous mitigating clauses in paragraph 2, especially the phrase 'having due regard for the provisions of articles 5 and 6' -the two equitable utilization articles. Finally, the proposition that the 'noharm' rule does not enjoy inherent preeminence is supported by Article 10 of the Convention, which provides that any conflict between uses of an international water course is to be resolved "with reference to Articles 5 to 7”. ... ${ }^{45}$

McCaffrey holds that the no-harm rule is not absolute. "It is mitigated by several factors, all of which depend upon the circumstances of the particular case; the harm must be 'significant'; the obligation is one of due diligence; and the harm must be unreasonable." 46 Joseph W. Dellapenna forwards the same view. "Experts on international water law have been nearly unanimous on the primacy of equitable utilization rule in international water". ${ }^{47}$

However, Iyad Hussein and Odeh Al-Jayousi have given emphasis to 'the noharm principle' stated in Article 5 of the 1993 'Framework for General Cooperation between Egypt and Ethiopia.'

The leading riparian state in terms of political and physical influence over the Nile is Egypt. The upstream states of both the Blue and the White Niles are in a weak position because of political and economical instability. During the early years of Egyptian independence, downstream dominance was

\footnotetext{
${ }^{44}$ Id. at $21-22$

${ }^{45} \mathrm{Id}$. at 22

${ }^{46} \mathrm{~S}$. McCaffrey, The Law of International Watercourses: Non-Navigational Uses Su-

47 Joseph W. Dellapenna, The customary international law of trasbounday fresh waters, International Journal of Global Environmental law, Vol. 1, Numbers 3/4 , p. 279 pra, Note 18, p. 380
} 
maintained in negotiation with the British over Sudan's water usage. In 1929, an agreement was reached between Egypt and Sudan that allocated the water of the Nile between these two parties. The Nile Waters Agreement was reassessed and finalized in 1959.

In July 1993, a general agreement grounded in international law was reached by downstream countries with the new Ethiopian government which may mark as the beginning of a new era of co-operation. This agreement included a clause that the upstream countries agreed not to act in a way that might harm the downstream states, and to consult and cooperate on future water projects that would be mutually beneficial."

The 1993 Agreement was merely a framework for co-operation and not a binding treaty ratified by Ethiopia. It is to be noted that the International Court of Justice (1994) rejected the enforceability of the 1935 Franco-Italian Treaty in the determination of the frontier line between Chad and Libya owing to the fact that the State Parties did not exchange the Treaty even if it was ratified by both France and Italy.

In addition to its non-ratification, the Ethio-Egyptian 1993 Framework entitled "Framework for General Cooperation", does not even use the term "Agreement" as nomenclature for the cooperation framework. The only provision which uses the term 'agree' is Article 4 which reads "The two parties agree that the issue of the use of the Nile waters shall be worked out in detail, through discussions by experts from both sides, on the basis of the rules and principles of international law". Now that the principle of equitable and reasonable utilization is the governing rule of customary international law and because the principle of equitable utilization is being unequivocally articulated at the Nile Basin Initiative, the details of use of the Nile waters to be worked out (as per Article 4) towards a binding legal framework would apparently be based on this principle of international law.

Article 5 of the Cooperation framework that reads "Each party shall refrain from engaging in any activity related to the Nile Waters that may create appreciable harm to the interests of the other party" expresses the 'no-harm' rule. However, even as a non-binding framework agreement, the provision ought to be interpreted pursuant to Article 31 of the 1969 Vienna Convention on the Law of Treaties that requires "good faith" and interpretation within the context of Article 4 (that provides for working towards a new legal

${ }^{48}$ Iyad Hussein and Odeh Al-Jayousi, Management of Shared Waters: A Comparison of International and Islamic Law, (IDRC Publications 2001), p.3 <http://www.idrc.ca/en/ev-93960201-1-DO TOPIC.html> 
framework in the use of the Nile waters based on rules and principles of international law), and together with Article 6 (that recognizes the need to enhance the volume and reduce the loss of Nile waters which inter alia necessitates reversal of the evaporation at Aswan High Dam), and the preamble that states commitment to principles of international law.

Both prior to and after 1993, Ethiopia has consistently expressed its right to equitable utilization of its transboundary water resources, and in effect, the no-harm rule cannot be the governing principle in Ethio-Egyptian relations. The rule can't thus be construed out of context to deny Ethiopians (in the Eastern Nile Basin) of their right to life, clean water, food and development. Nor does it confer upon Egypt a veto power to approve or disapprove Ethiopia's pursuits towards securing these basic rights to its citizens.

As Professor Dellapenna noted, the 1993 Agreement is ambiguous.

(The Agreement) is ambiguous enough that it does little to resolve future disagreements, particularly as the agreement did not establish even an ongoing consultative process. If one takes the promise not to inflict harm as controlling, the agreement benefits only Egypt. Egyptian activities on the Nile cannot inflict harm on Ethiopia, and Ethiopia has agreed to an Egyptian veto on Ethiopian projects to develop the waters of the Blue Nile and the Atbara. On the other hand, if one reads into the agreement to consult and cooperate on the basis of the principles of international law seriously, Ethiopia has gained Egyptian consent to the rule of equitable allocation without any absolute priority to preexisting uses. ${ }^{49}$

Moreover, the 1902 Anglo-Ethiopia Treaty does not vitiate Ethiopia's right to equitable utilization. Primarily, the treaty provision on the Nile watercourse is obsolete due to fundamental change of circumstances (rebus sic stantibus) as per Article 62 of the 1969 Vienna Convention on the Law of Treaties, and secondly, the treaty merely required Ethiopia not to "arrest" (i.e. cut off) the Nile waters, an act which is entirely different from Ethiopia's legitimate claims of equitable utilization without arresting the flow of the Nile waters.

\section{3- Bi-Dimensional Interpretation of the No-Harm Rule}

Although the no-harm rule is usually considered from the upper-lower ripiarian perspective in mainstream discourse, we can also consider the principle from the lower-upper riparian dimension. As McCaffrey noted “...

${ }^{49}$ Joseph W. Dellapenna, The Nile as a Legal and Political Structure, Supra, Note 12, P. 46 
just as a downstream state may be harmed by uses upstream, so also may an upstream state be harmed if its use is limited in favour of a state downstream." ${ }^{50}$ Deeper analysis of the no-harm principle thus clearly shows that Egypt would harm Ethiopia if it insists on denying the latter of its right to equitably utilize the Abbay-Atbara-Sobat water resources.

McCaffrey further stated that "[t]his demonstrates what Ronald Coase described as the 'reciprocal nature' of the problem. Since both States may be harmed, harm alone cannot be the decisive criterion." ${ }^{51}$ With regard to the purpose of the principle, he added "[t]he objective is to find a balance that results in the least harm to each, or which includes some form of compensation for the State that bears the greater portion of the harm.” Arriving at such a balance "may, particularly in areas of water shortage, necessitate the taking of measures to conserve water and to increase efficiency of use". ${ }^{52}$

Moreover, a distinction ought to be made between 'factual harm' and 'legal injury' and it must be noted that "It is only injury to 'a legally protected interest' that is prohibited." Such rights are equally protected, and any form of balance upon conflict of interest ought to be equitable and reasonable. “... An important basis of the entitlement to an equitable share is the notion of equality of right" and this principle "was recognized by the Permanent Court of International Justice in its 1929 decision in the River Oder case and confirmed most recently for non-navigational uses by the ICJ in the GabcikovoNagymaros case." 53

\section{Co-riparian Cooperation and sustainable utilization}

\section{1- Mindset shift towards cooperation}

As far back as 1908, Winston Churchill had said: “One day, every last drop of water which drains into the whole valley of the Nile ... shall be equally and amicably divided among the river people; and the Nile itself ... shall perish gloriously and never reach the sea." 54 However, it has taken too long for riparians of the Nile basin to pursue such path of equity, fraternity and cooperation. Yacob Arsano states the lack of adequate upstream-downstream water utilization and management and the "excessive erosion and land cover loss in upstream Ethiopia; flood and silt accumulation in the midstream Su-

\footnotetext{
50 Stephen McCaffrey, The Law of International Watercourses: Non-Navigational Uses Supra, Note 18, p. 327

51 Ibid

${ }^{52}$ Id. at 327 - 328

53 Id. at 329
Lori Pottinger, Can the Nile States Dam
Their Way to Cooperation? (International
Rivers Network- IRN) Backgrounder on the
Nile Basin Initiative, March 2004) p.1
} 
dan; and excessive water loss through evaporation in downstream Egypt." Dr. Yacob suggests watershed management and environmental protection at sub-regional level including "flood and drought management; mitigation of erosion and sedimentation; irrigation and drainage development; hydroelectric power development and pooling.” 55

The Nile Basin Initiative was established in 1999 "to help reduce tensions and create a framework for equitable sharing and 'cooperative development' of Nile water resources". ${ }^{56}$ The shared vision of NBI is "to achieve socioeconomic development through the equitable utilization of, and benefit from, the common Nile Basin resources".

The riparian States of Eastern Nile are currently working towards schemes of cooperation in the utilization and protection of the Blue Nile-Atbara-Sobat Basin. Within the framework of the Nile Basin Initiative, the Eastern Nile Subsidiary Action Plan (ENSAP) has designed a Joint Multipurpose Project (JMP) that targets at the development and management of the Eastern Nile Basin. In launching ENSAP, "the Eastern Nile Council of Ministers (ENCOM), agreed to 'ensure efficient water management and optimal use of resources through equitable utilization and no significant harm', to 'target poverty eradication' and to 'promote economic integration' ... “57

The first joint institution of Egypt, Ethiopia and Sudan (the Eastern Nile Regional Technical Office-ENTRO) "was established to oversee the preparation of the EN (Eastern Nile) investment program." The projects include "watershed management, flood preparedness, power interconnection, irrigation and drainage, and EN modeling”. The cooperation among the countries is meant to facilitate the "more complex work of addressing transboundary challenges and capturing the shared opportunities afforded by 'three countries, one system'." The cooperation is believed to enhance confidence building among Eastern Nile Basin countries and pave the path towards the equitable utilization and protection of the Eastern Nile waters.

Such schemes of cooperation need to gather further momentum and transform the motto 'three countries one system' into concrete reality through a binding multilateral treaty between all the Nile Basin Countries. This is feasible only if the yield of the Nile can be augmented through evaporation reduction and efficient utilization. Building dams in Ethiopian Highlands to save the volume that is exposed to excessive evaporation in the Egyptian

\begin{tabular}{l|l}
${ }^{55}$ Yacob Arsano, Supra Note 1, at 18 & ${ }^{57}$ JMP Launch Overview, Supra, Note 14, p \\
${ }^{56}$ Lori Pottinger, Supra, Note 54, p.1 &
\end{tabular} 
desert, and equitable reallocation of shares among co-riparians need to be points of focus if the current initiatives toward cooperation are to be real beyond declarations and promises. As Shlomi Dinar and Ariel Dinar remarked "Dale Whittington, John Waterbury, and Elizabeth McClelland ... argue that developments on the ground have necessitated a renegotiation of the 1959 Agreement", and it is suggested that it "should include such principles as the exploitation of joint gains, allocation of long-term water yields, and the establishment of regional water markets. ${ }^{58}$

It is to be noted that "the process of determining an equitable utilization is not imprisoned by the status quo. ... Nor is the delimitation of equitable utilization final at all times. Changing circumstances may require revaluation and a new determination." ${ }^{59}$ Riparians of Eastern Nile can thus determine the timeframe of their water resource allocation (to be two or three decades) so that figures can be renegotiated upon fundamental change of circumstances.

\section{2- The concern for sustainable utilization}

Sustainable development requires a prudent and reasonable balance between economic interests in utilizing resources and preservation of the resources to meet present and future needs. According to the Brundtland report entitled Our Common Future, sustainable development is defined as "development that meets the needs of the present without compromising the ability of future generations to meet their own needs." 60 The critical objectives identified in the report include conserving and enhancing the resource base and merging environmental concerns and economic interests in decision making.

Environmental concerns include 'human health and safety, flora, fauna, soil, air, water, climate, landscape and historical monuments or other physical structures or the interaction among these factors'.61 And, the need for cooperation between riparian states toward remedial and protective steps regarding these concerns is long overdue.

Article 20 of the 1997 UN Watercourses Convention provides that

\footnotetext{
58 Shlomi Dinar and Ariel Dinar, Recent Developments in the Literature on Conflict, Negotiation and Cooperation over Shared International Fresh Waters, Natural Resources Journal, Fall 2003, (43 Nat. Resources J. 1217) p. 1267

59 Jerome Lipper, Equitable Utilization, The International Law of International Drainage Basin, Edited by A. H. Garreston, R. D.

Bayton, C. J. Olmstead, (Published for the Institute of International Law, New York University School of Law, Oceana Publications, 1967) pp. 66, 67

${ }^{60}$ WCED, Our Common Future, 1987, p.43

${ }^{61}$ Philippe Sands, Principles of International Environmental Law, $2^{\text {nd }}$ Edition, (Cambridge University Press, 2003) p.17
} 
"Watercourse States, shall individually and, where appropriate, jointly, protect and preserve the ecosystems of international watercourses." And according to Article 5, Para 1 of the Convention, watercourse States shall use and develop an international watercourse "with a view to attaining optimal and sustainable utilization thereof and benefits therefrom, taking into account the interests of the watercourse States concerned, consistent with adequate protection of the watercourse".

The term "adequate” is ambiguous. Peter Beaumont discusses the ambiguity of the term "adequate" in relation to the protection of the watercourse. "It is well known that almost any use of water from a river is going to compromise some part of the river's ecosystem. The greater the use of water the more difficult it becomes to maintain the health of the ecosystem." According to Beaumont, "if human beings are to continue to use transboundary rivers it is obvious that their ecosystems cannot be returned to their pristine conditions." 62

Beaumont appreciates the 1997 Watercourses Convention despite its general provisions "that will cause many problems for negotiators dealing with realworld problems." Unfortunately, noted Beaumont, "this means that it will not be easy to use the document as a basis for discussions as the plethora of factors introduced in the Convention will result in many disputes arising."63

Stephen McCaffrey, on the other hand states that the Convention is a framework agreement and the level of precision that is found in many bilateral and multilateral instruments could not be expected at this level of its development. "It must be borne in mind that this is a universal, framework agreement. Because of this fact, one cannot expect either the level of detail or the degree of 'Greenness' that one might find in a bilateral or regional instrument." Therefore, the Convention is "intended to be supplemented by more detailed agreements concerning specific watercourses shared by two or more countries. ..., 64

Articles 24 to 26 "consider the management of an international watercourse in terms of its sustainable development", and require "the establishment of a joint management mechanism which will provide mutual benefits for all the states." The provisions consider "how the flow should be regulated and how installations ... should be maintained and utilized. Article 25 introduces the idea that states may be willing to share costs in the construction of a facility that will benefit all the riparian states." 65

${ }^{62}$ Beaumont, Supra, Note 33, p. 485

${ }^{64}$ McCaffrey, Supra Note 27, pp. 27- 28

${ }^{63}$ Id. at 494

${ }^{65}$ Beaumont, Supra, Note 33, page 485 


\section{3- The Quest for storage schemes at Ethiopian highlands}

Reallocation of equitable shares to co-riparians without significant harm to the status quo (inter alia) requires "proper river management (dams, reservoirs and so on) and engineering developments, especially in the Blue Nile region." Such holistic measures "would result in several advantages besides that of rescued Nile water from evaporation. For example, regulating the Blue Nile waters in Ethiopia would reduce flooding and sedimentation in the downstream countries," and could also "be used for hydro-power generation that could be rationed through trade to downstream users." 66

Storage schemes by constructing a number of reservoirs on headwaters of the Blue Nile have been advocated by many hydraulic experts. Such schemes not only regulate the variations in the flow of the Nile, but also avoid the loss of as much as fifteen billion cubic meters per year as a result of evaporation and seepage at Aswan High Dam. ${ }^{67}$ The major study that was launched by Ethiopia in 1958 in conjunction with the US Bureau of Reclamation in the Department of Interior was indeed exhaustive. It "proposed four major dams on the Blue Nile ... with a combined storage of 51 billion cubic meters..." According to Collins, "If all projects were completed ... the amount of land put into cultivation in Ethiopia would be equal to 17 per cent of the current land under irrigation in Egypt and would require six billion cubic meters of the Nile River.” 68

Collins attributed the failure of the project to Ethio-Egyptian hydropolitics: "[F]ears, stocked by misinformed nationalism have destroyed ... any holistic development of the Nile valley". Collins further noted that "ironically, the Blue Nile Plan, if properly managed would not substantially affect the water available to Egypt and the Sudan”. And he added, "Under appropriate working arrangements the amount of water for irrigation throughout the Nile basin could actually be increased. ..." ${ }^{69}$ The maximum loss of water due to evaporation (according to Collins) would be only 3\% at Ethiopian highlands as opposed to over $12 \%$ in the Aswan reservoir. ${ }^{70}$

Under Ethiopia’s 1958 Blue Nile Plan “the Sudan, for instance would receive 2.7 billion cubic meters more than the present allocation under the 1959 Nile

\footnotetext{
${ }^{66}$ Kefyalew Mekonnen, A New Basis for a Viable Nile River Water Allocation Agreement (The $5^{\text {th }}$ Nile 2002 Conference, Addis Ababa, February 2002) page 9

${ }^{67}$ Eyal Benvenisti, Collective Action in the Utilization of Shared Fresh Waters (American Journal of International Law, July 1996) P. 409 [in Girma Amare's The

Nile Waters: The Imperative Need for Negotiations and its Utilization; Presented at the International Conference on the Waters of the Nile, February 1997, Addis Ababa]

${ }^{68}$ Collins, Supra Note 2, at 279

${ }^{69}$ Id. at 481

${ }^{70}$ Id. at 482
} 
Waters Agreement”. ${ }^{71}$ Moreover, the four reservoirs that were planned to be constructed at the Blue Nile "in conjunction with a Rosiers reservoir (in Sudan) freed from debris and heavy siltation could then be released in May to reach Egypt when its water requirement is the highest without sustaining the heavy loss by evaporation now sustained at Aswan.” 72

\section{Concluding Remarks: Towards glasses "half-full”}

Although the Nile is the longest river in the World (with a length of 6,825 $\mathrm{kms}$ ), its annual discharge is one of the lowest among the world's major river systems. River Amazon, for example, is $125 \mathrm{kms}$ shorter than the Nile, but has an annual discharge of 3,000 (three thousand) billion cubic meters ${ }^{73}$ while Nile's annual discharge volume is about 80 billion cubic meters at a generous estimate that doesn't take the overall discharge decline trend (due to erratic rainfall and siltation) into account. It is despite such scarcity that co-riparians of the Nile ought to formulate and ratify a binding legal framework for the use, preservation and development of the Nile waters.

The Main Nile Sources are the Blue Nile, Sobat, Atbara and the Equatorial Lakes which respectively contribute $59 \%, 14 \%, 13 \%$ and $14 \%$ of the Nile waters. ${ }^{74}$ It is indeed a paradox that Ethiopia which contributes over $80 \%$ to the aggregate discharge utilizes only about $1 \%$ of the Nile waters. Needless to say, Ethiopia currently stands far below Egypt and Sudan in economic development, and in effect, every irrigation and hydroelectric project through equitable utilization of Eastern Nile's headwaters shall positively contribute towards its needs and rights to development.

Both Ethiopia and Egypt had their periods of drought and famine. The events that occurred in Egypt during the periods stated under Section 1.1 due to extremely low Nile flows, and the periodically recurrent famine in Ethiopia owing to drought unequivocally prove the role of water in the lives of Ethiopians, Sudanese and Egyptians. Article 11 of the International Covenant on Economic, Cultural and Social Rights recognizes "the right of everyone to be free from hunger." And by virtue of Article 90/1 of the Constitution of the Federal Democratic Republic of Ethiopia, "To the extent that the country's resources permit, policies shall aim to provide all Ethiopians access to public health and education, clean water, housing, food and social security”. With regard to the modalities of interpreting such rights to water, it has been suggested that in view of the often devastating results that are caused when individuals are denied fresh water, "the relevant provisions of existing human

\begin{tabular}{l|l}
\hline${ }^{71}$ Ibid & ${ }^{73}$ Waterbury, Supra Note 24, at 14 \\
${ }^{72}$ Ibid & ${ }^{74}$ Id. at 23 \\
\hline
\end{tabular}


rights instruments ought to be interpreted broadly, so as to facilitate the implementation of the right to water as quickly and comprehensively as possible." 75

The sovereignty of each riparian State in the Eastern Nile over its natural resources and the right of citizens to life, water and food is apparent. Yet, in view of the modest discharge of the Nile watercourse, each riparian State is expected to have pragmatic and reconciliatory Wisdom and Political Will based on a mindset that recognizes equitable shares as "half-full" instead of "half empty".

If the Nile were as generous as the Amazon River, allocation wouldn't have been an issue. However, the Nile (as discussed earlier) is at risk from the source of the headwaters (owing to environmental degradation) and throughout its journey (due to siltation and sedimentation). It is also mismanaged mainly due to inefficient irrigation and as a result of its exposure to extremely high evaporation and seepage at the Aswan High Dam. We need not thus be prophets to forecast upcoming dark moments unless there is reversal (inter alia) towards population stabilization, upper watershed reforestation, upstream storage schemes, efficient utilization and the equitable allocation of the Nile waters.

We can wrap up with just one question: If three members of a family can only afford to have a small loaf of bread at their dinner table, what would they do? The longer one of them is deprived of his/her equitable share, the more would it be difficult for them to be in harmony. It is even worse in the case of the Eastern Nile waters, because co-riparians are at crossroads to either join hands and rescue the flow of the headwaters, or procrastinate while events unfold towards their gradual extinction.

Postscript:

"The 15th Ordinary Nile Basin Council of Ministers (that) ended in Entebbe Uganda on 26 June 2007.... concluded its negotiations on the Nile River Basin Cooperative Framework Agreement. ...The Cooperative Framework calls for the establishment of a permanent Nile River Basin Commission through which the countries will act together to manage and develop the resources of the Nile. The Cooperative Framework Agreement must be adopted by all basin states and then ratified before entering into force as an international treaty. Once ratified, this historic agreement will be the first Nile Treaty to include all riparian states of the Nile River Basin. This achievement brings close to conclusion a 10year process of analysis and negotiation to establish the institutional structure and legal basis for cooperation in the management and development of the Nile River”. http://www.nilebasin.org/index.php?option=com_content\&task=view\&id=48\&Itemid=1

\footnotetext{
${ }^{75}$ Stephen C. McCaffrey, A Human Right to Water: Domestic and International Implications, Georgetown International Environmental Law Review (5 Geo. Int'l Envtl. L. Rev. 1) Fall, 1992, page 12
} 